\title{
Small is Beautiful? Niche Entrepreneurship with a Swiss Touch
}

\author{
Jung Eung Park ${ }^{1}$, Jim Pulcrano $^{1}$, Benoit Leleux ${ }^{1}$ \\ ${ }^{1}$ IMD (International Institute for Management Development), Lausanne, Switzerland \\ Correspondence: Jung Eung Park, IMD, Ch. de Bellerive 23, P.O. Box 915, CH-1001 Lausanne, Switzerland.
}

Received: February 20, 2020

Accepted: March 17, 2020

Online Published: March 20, 2020

doi:10.5539/ibr.v13n4p52

URL: https://doi.org/10.5539/ibr.v13n4p52

\begin{abstract}
Entrepreneurship in Switzerland seems to be the exact opposite of that in Silicon Valley and can be described as low-impact entrepreneurship, or niche-centric entrepreneurship. We used an online survey to investigate the characteristics of Swiss entrepreneurs, their business performance, activities in securing investments, as well as their expectations from supporting institutions. In addition, as an effective example of utilizing the ecosystem, we investigated the entrepreneurs' activities in venture competitions. We provide empirical evidence that supports the view that Switzerland, at least regarding high-tech, early stage companies, has a unique ecosystem low financial expectations, niche technology specialists, mostly angel and self-financed, high survival rates and clear success, defined via great products and innovation, and positive social/environmental impact.
\end{abstract}

Keywords: entrepreneurial ecosystem, entrepreneurship, Switzerland, venture competition

\section{Introduction}

Entrepreneurship has received great attention with successful, young, high-tech start-ups highlighted regularly in the popular media. The so-called unicorns, young companies valued at over 1 billion dollars, have inspired many. Moreover, due to the positive role start-ups play in creating new jobs, governments have attempted to promote entrepreneurship in their regions (Schwartz, Goethner, Michelsen \& Waldmann, 2013).

Silicon Valley, and the San Francisco Bay Area in general, is considered the global role model for an entrepreneurial ecosystem. According to Ernst and Young's annual survey (Schreiber \& Pinelli, 2013), the USA ranked best in terms of access to funding and the entrepreneurship culture. Moreover, Silicon Valley was ranked as the top ecosystem, attracting $47 \%$ of all venture capital invested in the USA in 2015, and $30 \%$ of all deals (Herrmann, Gauthier, Holtschke, Berman \& Marmer, 2015). Though northern California has been proposed as a role model for policy-makers in other countries, entrepreneurs, investors and government officials everywhere must find the model that best suits their region.

The different forms of capitalism in the USA and Germany have often been compared as they represent, respectively, the typical liberal market economy (LME) and coordinated market economy (CME) as presented in Hall and Soskice (2001). A CME, such as Germany, is perceived to have advantages that allow it to compete with LMEs. Witt and Redding (2012) found that typical US business leaders emphasized that the purpose of business is maximizing shareholder gains, thus focusing on business profitability. German executives often mentioned their attention to stakeholders in general, including their obligation to employees and impact on the society. Accordingly, different characteristics could be observed in each economy: workers in CMEs tend to develop firm-specific skills expecting long-term employment, while laborers in LMEs tend to develop general skills to adapt to a fluid labor market. CMEs usually seek incremental innovation with a quality-driven approach, while LMEs appreciate radical innovation, propelled by a market-driven approach. Hall and Soskice (2001) classified six countries as LMEs (USA, UK, Australia, Canada, New Zealand, Ireland) and another ten as CMEs (Germany, Japan, Switzerland, the Netherlands, Belgium, Sweden, Norway, Denmark, Finland and Austria). Nevertheless, the characteristics of each country vary, and within a large country such as the USA there will be regional differences. Silicon Valley seems to be the epitome of an LME, an ecosystem without unions, workers with transferable skills who move from company to company, a focus on impatient, short-term capital, and competitive arms-length relationships between companies.

In this paper, we provide the first instance of empirical research that supports the view that Switzerland, at least regarding high-tech, early stage companies, has a different ecosystem entirely - low financial expectations, niche technology specialists, mostly angel and self-financed, high survival rates and success defined via great products 
and innovation and positive social/environmental impact. In that sense, the entrepreneurship in Switzerland seems to be the exact opposite of that of Silicon Valley and can be described as low-impact entrepreneurship or niche-centric entrepreneurship.

We used an online survey to understand the characteristics of Swiss entrepreneurs, their business performance, activities in securing investments, as well as their expectations from supporting institutions. In addition, as one of the effective examples of utilizing the ecosystem, we investigated the entrepreneurs' activities in venture competitions. The number of available venture competitions has increased as governments aim to encourage entrepreneurship as an economic stimulus (Schwartz et al., 2013).

\section{Method}

We used an online survey with both quantitative and qualitative questions. As two of the authors have organized a venture competition for Swiss start-ups since 1998, one group of surveyed companies were the winners of the annual IMD startup competition. The IMD startup competition does not provide a financial reward, but connects each winning venture with a group of experienced international MBA or Executive MBA (EMBA) students. While the start-ups provide a hands-on learning experience in entrepreneurship for the MBA and EMBA classes, the students provide coaching, contacts, insights and support to the companies, to improve their chances of funding and success. The companies are Swiss ventures, typically at an early stage but with a team and resources already in place. A second survey group consisted of Swiss start-ups which were not laureates of the IMD startup competition.

In November 2015 an email was sent to 249 entrepreneurs in the first group and 184 entrepreneurs in the second group - a total of 433 entrepreneurs based in Switzerland or who had worked in Switzerland in the past. To increase the response rate and to encourage them to complete the questionnaire without dropping out, respondents were allowed to skip questions if they did not wish to reveal sensitive information such as revenue. After one week, we sent reminders to the companies who had not yet filled in the online questionnaire.

A total of 193 responses were received; 112 entrepreneurs from the first group (45\%) and 81 from the second group (44\%). There is a risk of selection bias in the data, as many of the responding entrepreneurs know, or know of, one or more of the authors. As the IMD startup competition has a good reputation in Switzerland, the survey receivers may wish to maintain a good relationship with IMD or the authors for future collaboration.

The questions in the survey were divided into three categories: venture competition activities, company status and network ties within the Swiss entrepreneurial ecosystem. We deleted 19 responses that were significantly incomplete. Unlike face-to-face interviews, online surveys do not provide an opportunity to judge the care with which respondents fill in the data. In cases where the answers seemed inconsistent, we contacted the respondents for verification.

\section{Results}

\subsection{Characteristics of Swiss Entrepreneurs}

The start-ups of the respondents were founded mostly between 1999 and 2015 (one company was founded in 1980 and a few were not yet incorporated). The largest portion of the companies is in life sciences, software and engineering. At the time of the survey, $83 \%$ of the companies were still active.

Figure 1 shows the industry categories of the respondents. As multiple choices were allowed in the 20 listed categories, the sum of answers from all categories is more than the number of respondents. Almost one-third of the companies were in life sciences and software. Engineering and data-related industries were the next popular categories that respondents belonged to. 


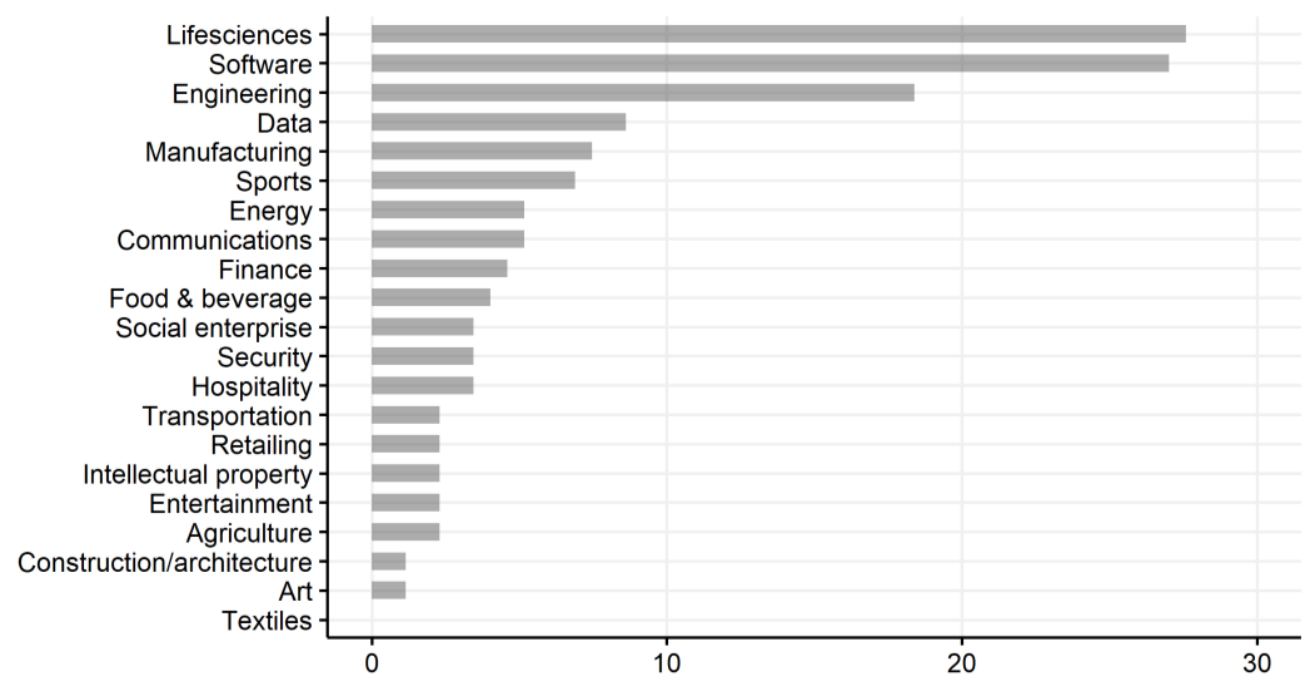

Figure 1. Industry categories of the respondents

Multiple founders were the rule, with $86 \%$ of the companies founded by more than one person, and in $35 \%$ of cases there were three co-founders. This may be one of the factors behind the relatively high survival rate of Swiss start-ups since, according to Startup Genome (Marmer, Herrmann, Dogrultan \& Berman, 2011), solo founders take 3.6 times longer to reach scale stage compared with a founding team of two and they are 2.3 times less likely to pivot, based on the data of 663 web start-ups in the Silicon Valley area.

Each entrepreneur has their own definition of success. Survey participants were asked to indicate their agreement with various descriptions related to definitions of success, from 0 (= strongly disagree) to 10 (= strongly agree). For these questions, a neutral value of 5 was given to each description as a default to minimize the impact of skipped answers. As shown in Figure 2, Swiss entrepreneurs valued revenue growth as the top indicator of success. But noticeably, great product and innovation also found an equivalent level of agreement. Entrepreneurs in Switzerland seem to put value not only on financial success but also on innovative technical/product achievements.

The Startup Genome report (Marmer et al., 2011) investigated the motivation of entrepreneurs in web start-ups in Silicon Valley and reported that 'building great products' (43\%) and 'changing the world' (38\%) were their primary motivation to establish a start-up rather than 'making a good living' (14\%) or 'create a quick flip' (5\%). In addition, they also reported that entrepreneurs care mostly about 'impact' $(68 \%)$ and 'experience' (27\%) but not so much about 'money' $(5 \%)$.

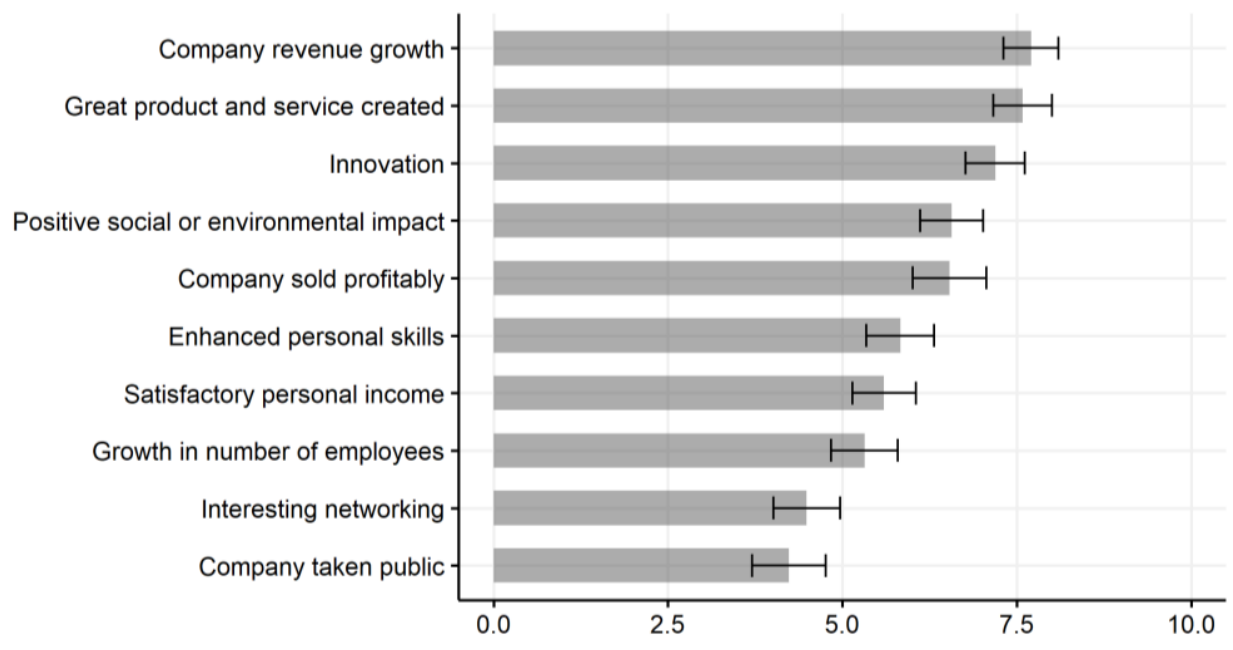

Figure 2. Definition of success with a scale from 0 (disagree) to 10 (strongly agree) 


\subsection{Business Performance of Swiss Start-Ups}

Table 1 shows the current status of the company. Most companies (144 out of 174, 83\%) are still active. There is a risk of bias that only active companies participated in the survey.

Table 1 . Company status

\begin{tabular}{lcc}
\hline Company status & Count & Percentage \\
\hline Active & 144 & $82.8 \%$ \\
Sold to another company with losses for some stakeholders & 7 & $4.0 \%$ \\
Discontinued operation with no losses to creditors & 6 & $3.4 \%$ \\
Orderly liquidation with no losses to creditors & 5 & $2.9 \%$ \\
Sold to another company with stakeholders left whole & 5 & $2.9 \%$ \\
Strategic reorientation of activities or major pivot & 4 & $2.3 \%$ \\
Merged with another company and continued activity there & 2 & $1.1 \%$ \\
Bankruptcy with losses to creditors & 1 & $0.6 \%$ \\
\hline
\end{tabular}

Not all the inactive companies can be considered as failures. The number of companies which caused losses for stakeholders and creditors were only 5\% of the respondents. As a comparison, CTI research report (2011) shows similar results where the authors investigated the status of all Swiss start-ups which were examined and endorsed by CTI between 1996 and 2010. CTI (Commission for Technology and Innovation, renamed Innosuisse from 2018) is an arm of the Swiss Federal Government, supporting innovation and entrepreneurship through coaching, training, networking and R\&D investments (see Appendix A). Among the CTI-surveyed 243 companies, 85\% were still active or sold to others without loss; similar to our results.

Another Swiss point of comparison is the ventures supported by Venture Kick. Of the 100 start-ups supported in the 2007-2009 period, 26 disappeared, and only 12 of these 26 were actually incorporated companies. The 82 projects supported with the maximum funding of CHF 130,000, from 2007 through 2015, showed a much higher level of sustainability, with only three stopped altogether and the remaining 79 creating 19 jobs each on average (Venture Kick, 2015).

MassChallenge reported that over the four years since its inception in October 2010 they had 65 companies stop activity altogether, 24 were acquired and 528 were still active, giving a survival rate of $86 \%$ (MassChallenge, 2014).

In an international comparison unrelated to venture competitions, the IVC Research Center investigated 10,185 Israeli and Israel-related high-tech companies established between 1999 and 2014 (IVC Research Center, 2015). Over $46 \%$ had been closed within 3.2 years on average, while the remainder continued to be active in various stages of development. Table 2 shows the overall comparison of those statistics. The statistics must be considered carefully as the methods and samples are not consistent throughout the research studies.

Table 2. Comparison of survival rates from different research

\begin{tabular}{ccl}
\hline Source & Survival rate & Description \\
\hline IMD & $83 \%$ & $\begin{array}{l}\text { Status in 2015 of 174 selected start-ups by IMD, supported from 1999 to 2014 in } \\
\text { Switzerland } \\
\text { Status in 2016 of } 403 \text { selected start-ups by Venture Kick, supported from 2007 } \\
\text { to 2015 in Switzerland } \\
\text { Status in 2011 of selected start-ups by CTI, supported from 1999 to 2009 in } \\
\text { Switzerland (Gantenbein, Herold \& Zaby, 2011) }\end{array}$ \\
CTI & $85 \%$ & $\begin{array}{l}\text { Five-year survival rate of CTI selected start-ups in Switzerland (Gantenbein et } \\
\text { al., 2011) }\end{array}$ \\
CTI & $76 \%$ & $\begin{array}{l}\text { Five-year survival rate of companies in the secondary sector in Switzerland } \\
\text { (Gantenbein et al., 2011) }\end{array}$ \\
CTI & $58 \%$ & $\begin{array}{l}\text { Five-year survival rate in overall economy in Switzerland (Gantenbein et al., } \\
\text { 2011) } \\
\text { Status in 2014 of 617 selected start-ups by MassChallenge, supported from 2009 } \\
\text { to 2014 worldwide }\end{array}$ \\
MastChallenge & $89 \%$ & Status in 2015 of 10,185 Israeli start-ups founded from 1999 to 2014 \\
IVC Research & $86 \%$ &
\end{tabular}

Table 3 shows the annual revenue of the companies in CHF. Skipped answers were considered as 'not disclosed' 
and excluded from our data analysis. The majority of the surveyed companies increased their revenue over the years. However, it is noticeable that only one-tenth of the companies reached the maximum revenue of over CHF 5 million.

Not reaching over CHF 5 million in revenue is certainly not a reason to label a venture a failure, but there appears to be an ethos in Switzerland that 'small is beautiful', and pushing for scale is not necessary, or even desirable. One of the survey respondents described the behavior as:

Too often start-ups are not pushed or encouraged to take calculated risks, or go beyond their local horizons and, perhaps, fail. More often than not success is determined by not failing.

Table 3. Revenue changes

\begin{tabular}{ccc}
\hline Revenue $(\mathrm{CHF})$ & As of Today & At the peak \\
\hline more than 5m & $6 \%$ & $10 \%$ \\
more than $1 \mathrm{~m}$ to $5 \mathrm{~m}$ & $9 \%$ & $13 \%$ \\
more than 500k to $1 \mathrm{~m}$ & $11 \%$ & $10 \%$ \\
more than 250k to 500k & $10 \%$ & $8 \%$ \\
more than 100k to 250k & $11 \%$ & $5 \%$ \\
more than 50k to 100k & $4 \%$ & $6 \%$ \\
more than 20k to 50k & $6 \%$ & $8 \%$ \\
more than 0 to 20k & $9 \%$ & $27 \%$ \\
\hline
\end{tabular}

Table 4 shows the number of full-time employees in the companies. Skipped answers were again considered as 'not disclosed' and excluded from our data analysis. Two-third of the disclosed companies had an employee size of fewer than 10 even at their peak period, while only $4 \%$ of the companies ever reached over 100 employees.

Table 4. Employee size changes

\begin{tabular}{ccc}
\hline Employee size & As of Today & At the peak \\
\hline $501+$ & $0 \%$ & $1 \%$ \\
$101-500$ & $1 \%$ & $3 \%$ \\
$51-100$ & $3 \%$ & $5 \%$ \\
$31-50$ & $1 \%$ & $3 \%$ \\
$21-30$ & $4 \%$ & $5 \%$ \\
$11-20$ & $13 \%$ & $24 \%$ \\
$6-10$ & $19 \%$ & $37 \%$ \\
$2-5$ & $40 \%$ & $4 \%$ \\
1 (just me) & $9 \%$ & $3 \%$ \\
\hline
\end{tabular}

In an open question, entrepreneurs were asked to cite the most important difficulties they encountered in Switzerland. Many indicated that early stage funding was the most difficult issue.

Getting funding in the early stage when the technology was robust but the replicability had not been fully demonstrated. Investors seemed loath to take risks and had timelines that were too short ...

Timing issues: the feeling that when we had a good idea, it was not a topic 'in fashion'for VCs; then when potential investors have started to understand, first customers (big players) changed strategic priorities. Difficult to have all the green lights simultaneously. VCs don't take enough risks in Switzerland.

In addition, they indicated that convincing Swiss customers to try novel technologies is difficult.

Convincing prospects we would be around long enough to matter to them! Remember the old adage 'you won't get fired for choosing IBM'? Well, the life science industry is extremely conservative when it comes to sourcing software ...

In general, gaining trust in Switzerland is hard. We started to sell abroad and we still don't have many clients in Switzerland ...

A Swiss venture capital report (Startupticker.ch, 2016) reveals that life science companies obtained the largest sum of venture capital in 2015, representing about $72 \%$ of the financing volume. Next, ICT companies, including fintech, obtained $19 \%$ while all other sectors played a minor role taking the remained $9 \%$. As a 
comparison (IVC Research Center, 2015), in Israel, the internet/software/cleantech/life science sectors represented $31 \%, 27 \%, 13 \%, 11 \%$ of the total invested capital respectively. Although Israel is similar to Switzerland in terms of population (8.4-8.9 million in Israel and 8 million in Switzerland) and with a high ratio of scientists and technology professionals (4.27\% and $3 \%$ respectively), the diversity of sectors was much higher in Israel.

\subsection{Support from Local Ecosystems}

Table 5 shows the types of external financial resources that the entrepreneurs could attract. The most popular types were family and friends and angel investors, followed by supporting organizations such as government and universities. The portion of venture capital backed investment was $16 \%$, while the portion of companies which received no external support was $11 \%$.

Table 5. External investment

\begin{tabular}{ccc}
\hline External financial support & Count & Percentage \\
\hline Family and friends & 97 & $56 \%$ \\
Angel investors & 90 & $52 \%$ \\
Government, university or support organizations & 59 & $34 \%$ \\
Venture capitalists & 28 & $16 \%$ \\
Others & 26 & $15 \%$ \\
Bank loans & 26 & $15 \%$ \\
Corporate investors & 24 & $14 \%$ \\
None & 20 & $7 \%$ \\
Bank equity investments & 13 & $3 \%$ \\
Crowdfunding online & 6 & $3 \%$ \\
\hline
\end{tabular}

Note. Multiple choices were allowed.

Survey participants were asked in an open question what they wanted to change in the local ecosystem to be more supportive of entrepreneurial ventures.

As mentioned previously, increased funding access was cited as their major wish for the Swiss ecosystem, describing risk-adverse attitudes by investors, the lack of large venture capital investments for fast-growing start-ups that want to scale, and the slow speed of the investment processes.

Many entrepreneurs commented on Swiss incubators:

Incubators and technoparcs offer mainly offices to rent, but too-limited services. These places should be more specialized in a domain and offer real support specific for start-ups in a given domain (medtech, fintech, ICT, etc.). It should then be possible for the start-up to spend less time looking for investors, for consultants (e.g. in medtech, a basic quality system designed for a small start-up could rapidly be adapted to each project).

Start-up incubators in Switzerland: we don't need buildings, we need access to capital and talents, customers for early feedback, lots more exchange with peer entrepreneurs.

More incubators and accelerators programmes! The cost of launching a start-up in Switzerland is very high.

Offer support with setting up basic business functions, including basic documentation (e.g. standard work contracts, etc); this would be a simple and very effective measure.

Some entrepreneurs complained that the Swiss ecosystem favors only a few select industries such as biotech and fintech, and is product dominated. From their comments, it appears that entrepreneurs with business-model driven ventures have difficulty in Switzerland. Seeing their peers being actively supported in the USA and Germany, they feel that their innovations are not respected in Switzerland.

We have a good idea and business plan, but as it is not highly technological and uses existing technology it is difficult to get start-up capital ...

There is little space for e-commerce start-ups to exist in the ecosystem. Most of the time they are not considered seriously. E-commerce start-ups receive less attention in Switzerland than the others (fintech, biotech ...) in comparison to the US ecosystem or even the French one ... 
The Swiss ecosystem for start-ups is extremely focused on biotech. I would love to see more openness ...

Entrepreneurial activities in the field of services receive less attention from the Swiss start-up ecosystem, which means [these] companies have less access to competitions and attention from the experts.

The local ecosystem is very supportive when you're at the early stage, but it discriminates vis à vis companies which have no link to Swiss universities.

The current ecosystem forgets about service ventures that could be very innovative and profitable as well.

The ecosystem is very product driven. If you're innovating on the business model side it will be harder to raise funds.

The whole system shows a strong, maybe too strong, dependence on established economic sectors within the local technology investment culture.

Give more credit and support to non-tech based start-ups.

\subsection{Activities in Swiss Venture Competitions}

In this section, we present results on start-ups' activities in venture competitions, as one example of a supporting ecosystem. Figure 3 shows the numbers of start-ups participating and winning popular competitions. Ten popular Swiss venture competitions were provided in the survey. We asked whether the respondents participated in and won for each of the competitions. Descriptions of the venture competitions is provided in Appendix A.

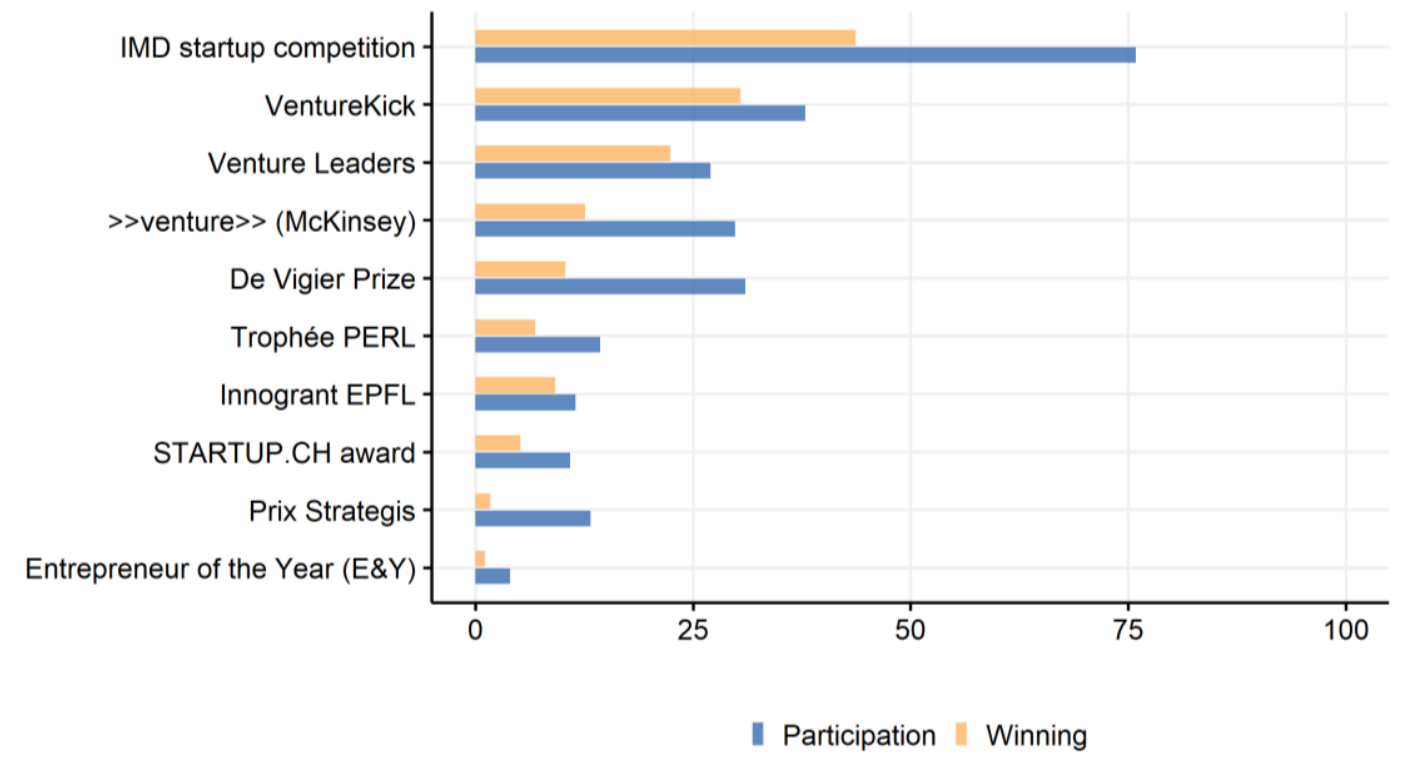

Figure 3. Participation in and winning in venture competitions shown in percentage [\%] over the total number of respondents

Due to the survey selection bias, the IMD startup competition appeared the most popular competition, as many of the survey participants were winners, non-winning participants or future applicants (the number of candidates for the IMD competition increased from 15 companies in 1998, to 74 in 2014 and 123 in 2015).

Other than the IMD startup competition, Venture Kick is the most popular in Switzerland (in its first year, 2007, Venture Kick financially supported 16 ventures; in 2015 this number reached 53, from 365 applications $14.5 \%)$.

The success rates of Venture Kick and Venture Leaders seem to be higher than other competitions among the current survey respondents, though from looking purely at the number of applications and acceptances, this is not the case.

Survey participants were also asked to write the total numbers of competitions they had participated in, and won. We excluded skipped answers. Among the entrepreneurs who participated in at least one venture competition, they participated in venture competitions 4.2 times and won 2.3 times on average. 
In addition, we asked entrepreneurs to name competitions that they participated in but that were not listed in the survey. The most frequently mentioned competitions were Heuberger Winterthur Jungunternehmerpreis (19 times mentioned), Swiss Technology Award (18 times) and Swiss Economic Award (14 times). By comparison, of the listed venture competitions in Figure 3, the lowest was EY's Entrepreneur of the Year award, which had seven respondents saying that they had participated, and two were winners.

Table 6 presents expected and obtained outcomes that entrepreneurs who won the IMD startup competition (first group). For the non-IMD group (second group), the questions were slightly different. We asked what their expectations were in general when participating in venture competitions. The IMD winners expected reputation improvement, financial rewards and networking, while those participating in other competitions were primarily seeking financial rewards, followed by reputation help. As regards the actual outcomes, the IMD startup competition was differentiated from other competitions in general by the actual outcome of 'receiving advice on the company'. It would appear that all winners were disappointed by the financial rewards that competitions gave them access to.

Table 6. Actual outcomes from venture competitions

\begin{tabular}{cccccc}
\hline & Expected & & & Obtained & \\
\cline { 2 - 3 } \cline { 5 - 6 } Outcomes & First group & Second group & & First group & Second group \\
\hline Improve reputation & $54 \%$ & $47 \%$ & & $25 \%$ & $33 \%$ \\
Achieve financial reward & $42 \%$ & $58 \%$ & & $4 \%$ & $26 \%$ \\
Expand network & $40 \%$ & $38 \%$ & & $61 \%$ & $37 \%$ \\
Receive advice on the company & $30 \%$ & $34 \%$ & & $67 \%$ & $23 \%$ \\
Increase pride / morale of my team & $17 \%$ & $10 \%$ & & $8 \%$ & $12 \%$ \\
Learn specific skills & $15 \%$ & $10 \%$ & & $26 \%$ & $10 \%$ \\
\hline Number of respondents & 101 & 73 & & 101 & 73 \\
\hline
\end{tabular}

Note. First group represents the winners of IMD startup competition while second group represents those who didn't get the IMD reward given to the winners.

Table 7 presents regression results of getting IMD rewards on various outcome expected from the competitions. Except model 1 showing the correlation between the support and the impact on the entrepreneur, all the models included control variables to test the relationships with different dependent variables. We have provided the regression coefficient, standard error, and p-value as the level of significance. The results in models 2 and 3 show that the coefficient for the impact on entrepreneur 1.040 was significant at the .01 level while the coefficient for the impact on company cannot be judged with statistical significance. The winners of the IMD startup competition were rewarded with the opportunity to collaborate closely with either IMD's full-time MBA class (average age 31, 5-8 years' experience) or EMBA class (average age 40, 15 years' experience). The students and entrepreneurs typically work together over several months, towards a common goal. With the MBAs, usually it is a targeted project to bring value to the start-up, while with the EMBAs it consists of coaching, and then joining the class for a one-week total immersion expedition to Silicon Valley, where the EMBA students pitch the venture to local venture capitalists and angels. Thus, the intense time spent together, collaborating, probably accounts more for the personal impact on the entrepreneurs. Model 3 to 7 show that IMD startup competition provided advice and helped expanding network effectively while not providing financial rewards.

Table 7. Linear regression for the impact of venture competitions

\begin{tabular}{|c|c|c|c|c|c|c|c|}
\hline & \multicolumn{7}{|c|}{ Dependent variable: } \\
\hline & $\begin{array}{c}\text { ImpactOn } \\
\text { (1) }\end{array}$ & $\begin{array}{l}\text { repreneur } \\
\text { (2) }\end{array}$ & $\begin{array}{c}\text { ImpactOnCompany } \\
\text { (3) }\end{array}$ & $\begin{array}{l}\text { LearnSkill } \\
\text { (4) }\end{array}$ & $\begin{array}{c}\text { Advice } \\
\text { (5) }\end{array}$ & $\begin{array}{c}\text { FinancialReward } \\
\text { (6) }\end{array}$ & $\begin{array}{c}\text { Network } \\
\text { (7) }\end{array}$ \\
\hline IMDreward & $\begin{array}{l}0.581^{* *} \\
(0.282)\end{array}$ & $\begin{array}{l}1.040^{* * *} \\
(0.426)\end{array}$ & $\begin{array}{l}-0.362 \\
(0.445)\end{array}$ & $\begin{array}{c}0.157 \\
(0.111)\end{array}$ & $\begin{array}{l}0.574^{* * *} \\
(0.121)\end{array}$ & $\begin{array}{l}-0.175^{* *} \\
(0.078)\end{array}$ & $\begin{array}{l}0.253^{* *} \\
(0.125)\end{array}$ \\
\hline YearFoundation & & $\begin{array}{c}0.001 \\
(0.037)\end{array}$ & $\begin{array}{c}0.024 \\
(0.040)\end{array}$ & $\begin{array}{c}0.011 \\
(0.010)\end{array}$ & $\begin{array}{c}0.009 \\
(0.011)\end{array}$ & $\begin{array}{l}-0.001 \\
(0.007)\end{array}$ & $\begin{array}{c}0.003 \\
(0.011)\end{array}$ \\
\hline RevenuePeak & & $\begin{array}{l}-0.073 \\
(0.068)\end{array}$ & $\begin{array}{c}0.010 \\
(0.078)\end{array}$ & $\begin{array}{c}0.005 \\
(0.018)\end{array}$ & $\begin{array}{c}0.002 \\
(0.019)\end{array}$ & $\begin{array}{l}-0.004 \\
(0.012)\end{array}$ & $\begin{array}{l}-0.052^{* *} \\
(0.020)\end{array}$ \\
\hline
\end{tabular}




\begin{tabular}{|c|c|c|c|c|c|c|c|}
\hline NumEmployeePeak & & $\begin{array}{l}-0.129 \\
(0.112)\end{array}$ & $\begin{array}{l}-0.148 \\
(0.122)\end{array}$ & $\begin{array}{c}0.022 \\
(0.030)\end{array}$ & $\begin{array}{l}-0.025 \\
(0.032)\end{array}$ & $\begin{array}{l}-0.004 \\
(0.021)\end{array}$ & $\begin{array}{c}0.029 \\
(0.034)\end{array}$ \\
\hline TotalNumCompetition & & $\begin{array}{c}0.074 \\
(0.101)\end{array}$ & $\begin{array}{l}-0.104 \\
(0.106)\end{array}$ & $\begin{array}{c}0.023 \\
(0.027)\end{array}$ & $\begin{array}{l}-0.013 \\
(0.029)\end{array}$ & $\begin{array}{c}0.029 \\
(0.019)\end{array}$ & $\begin{array}{c}0.006 \\
(0.030)\end{array}$ \\
\hline TotalNumWin & & $\begin{array}{l}-0.071 \\
(0.126)\end{array}$ & $\begin{array}{c}0.210 \\
(0.140)\end{array}$ & $\begin{array}{l}-0.033 \\
(0.034)\end{array}$ & $\begin{array}{l}-0.031 \\
(0.037)\end{array}$ & $\begin{array}{l}-0.013 \\
(0.024)\end{array}$ & $\begin{array}{c}0.022 \\
(0.038)\end{array}$ \\
\hline Constant & $\begin{array}{l}2.294^{* * *} \\
(0.228)\end{array}$ & $\begin{array}{c}0.469 \\
(75.550) \\
\end{array}$ & $\begin{array}{l}-45.027 \\
(79.865) \\
\end{array}$ & $\begin{array}{l}-22.068 \\
(20.367) \\
\end{array}$ & $\begin{array}{l}-17.756 \\
(22.226) \\
\end{array}$ & $\begin{array}{c}2.618 \\
(14.295) \\
\end{array}$ & $\begin{array}{c}-5.825 \\
(23.034) \\
\end{array}$ \\
\hline Observations & 147 & 106 & 101 & 118 & 118 & 118 & 118 \\
\hline $\mathrm{R}^{2}$ & 0.028 & 0.104 & 0.067 & 0.032 & 0.202 & 0.103 & 0.133 \\
\hline Adjusted $\mathrm{R}^{2}$ & 0.022 & 0.050 & 0.007 & -0.020 & 0.159 & 0.055 & 0.086 \\
\hline Residual Std. Error & $\begin{array}{c}1.630(\mathrm{df}= \\
145)\end{array}$ & $\begin{array}{c}1.524(\mathrm{df}= \\
99)\end{array}$ & $1.578(\mathrm{df}=94)$ & $\begin{array}{c}0.420(\mathrm{df}= \\
111)\end{array}$ & $\begin{array}{c}0.459(\mathrm{df}= \\
111)\end{array}$ & $0.295(\mathrm{df}=111)$ & $\begin{array}{c}0.476(\mathrm{df}= \\
111)\end{array}$ \\
\hline F Statistic & $\begin{array}{l}4.232^{* *}(\mathrm{df} \\
=1 ; 145)\end{array}$ & $\begin{array}{l}1.919^{*}(\mathrm{df} \\
=6 ; 99)\end{array}$ & $1.126(\mathrm{df}=6 ; 94)$ & $\begin{array}{c}0.612(\mathrm{df}= \\
6 ; 111)\end{array}$ & $\begin{array}{l}4.689^{* * * *}(\mathrm{df} \\
=6 ; 111)\end{array}$ & $\begin{array}{c}2.132^{*}(\mathrm{df}=6 \\
111)\end{array}$ & $\begin{array}{l}2.845^{* * *}(\mathrm{df} \\
=6 ; 111)\end{array}$ \\
\hline
\end{tabular}

Note. Impacts on entrepreneur and company were measured by a scale from 1 to 5 . The other dependent variables and IMD reward are binary, thus either 0 (no) or 1 (yes). ${ }^{*} \mathrm{p}<0.1 ;{ }^{* *} \mathrm{p}<0.05 ;{ }^{* * *} \mathrm{p}<0.01$

\section{Discussions and Conclusions}

An online survey was conducted to investigate the environment and characteristics of start-ups in Switzerland, including their activities in venture competitions. We collected data from a group of entrepreneurs who won the IMD startup competition (1999-2015) and compared them with data from entrepreneurs who were not laureates of the IMD startup competition.

\section{Who are they?}

- Life science and software are the top two major industries amongst Swiss start-ups.

- Less than $15 \%$ of the companies were founded by one founder.

- Swiss entrepreneurs define success both financially, and as the creation of innovative technological products and services.

\section{How is their performance?}

- They have difficulty in landing investors and penetrating markets in a timely manner.

- Swiss entrepreneurs have a high rate of survival (83\%).

- Only one-tenth of the companies reached revenue of more than CHF 5 million.

- Swiss entrepreneurs rarely seem to create large companies.

- The Swiss ecosystem seems to be adverse to 'new business models' and service start-ups, preferring technical product companies, which may at least partially explain the previous two points.

\section{What do they need from local ecosystems?}

- $16 \%$ of the surveyed companies received venture capital investments, while more than half received funding from angel investors.

- One-third of the companies received financial support from the Government, universities or support organizations.

- From the ecosystem, they expect local access to financing at an early stage as well as diverse services to handle different challenges encountered in running a venture in an expensive country.

\section{Activities in venture competitions}

- The major purpose of participating in venture competitions was to achieve financial rewards, to improve reputation and to expand their networks.

- While competitions met the major expectations of the winning entrepreneurs in general, the top actual outcome was expanding their networks. 
- From the IMD startup competition, the advice received from the MBAs and EMBAs was the most widely appreciated outcome.

- The IMD startup competition impacted more on the entrepreneurs personally than on their companies.

- For the companies which participated in at least one competition, they participated in venture competitions 4.2 times and won 2.3 times on average.

- Besides the IMD startup competition, the most popular competitions include Venture Kick, DeVigier, >>venture >> (McKinsey) and Venture Leaders.

\section{Recommendations for supporting organizations}

- The environment and characteristics of Swiss start-ups are different from those in Silicon Valley - for example, few Swiss start-ups are supported by large venture capital investments - and thus care should be taken in making this comparison.

- Given the low failure rate of Swiss-based start-ups, investors may find them attractive, despite the fact that few achieve dramatic financial success.

- Supporting organizations should decide whether they wish to change the Swiss ecosystem or keep and promote the characteristics of niche-centric entrepreneurship.

- Supporting organizations can help entrepreneurs accessing local investors and facilitating the investment decision process, but the most important contribution may be in helping Swiss start-ups to scale up, given the large numbers of ventures which never get over CHF 5 million in revenue.

- Moreover, supporting organizations, such as incubators and accelerators, can provide much needed support for the running of a business to save time and effort for new entrepreneurs in a high-cost environment, rather than simply renting inexpensive office space.

\section{Recommendations for entrepreneurs}

- Entrepreneurs seeking patient capital and an emphasis on technical and/or product achievements may find Switzerland to their liking. If your company is low-tech, service oriented or focused on a new business model with existing technology, you may find it difficult to raise money and get attention in Switzerland currently.

Switzerland is characterized by economists as being a CME, and in the sense that it is different from an LME, as epitomized by Silicon Valley, our data would seem to bear this out. On the other hand, there are differences with the economists' definition that point towards Switzerland being special, perhaps a niche economy where start-ups are concerned: low financial expectations, niche technology specialists, mostly angel and self-financed, high success rates, and success defined as great products and innovation and a positive social/environmental impact.

These results are expected to provide foundations for further discussions on improving the entrepreneurial ecosystem in Switzerland and other places that don't fit the Silicon Valley paradigm.

\section{References}

CTI (Commission for Technology and Innovation). (2011). Seed funding from foundations for Swiss technology startups. Basel, Switzerland: CTI.

Gantenbein, P., Herold, N., \& Zaby, S. (2011). Die KTI-Start-up-Förderung für innovative Schweizer Jungunternehmen - Ein empirischer Vergleich gelabelter und nichtgelabelter Unternehmen. Basel, Switzerland: KTI.

Hall, P. A., \& Soskice, D. (2001). An introduction to varieties of capitalism. In P.A. Hall \& D. Soskice (Eds.), Varieties of capitalism: The institutional foundations of comparative advantage (1-68). Oxford, UK: Oxford University Press. https://doi.org/10.1093/0199247757.001.0001

Herrmann, B., Gauthier, J., Holtschke, D., Berman, R., \& Marmer, M. (2015). The Global Startup Ecosystem Ranking. San Francisco, USA: Compass.

IVC Research Center. (2015). Israeli startup success report 1999-2014. IVC and REVERSEXIT report. Tel Aviv, Israel: IVC Research Center.

Marmer, M., Herrmann, B. L., Dogrultan, E., \& Berman, R. (2011). Startup Genome Report: A new framework for understanding why startups succeed. Berkley University and Stanford University, Tech. Rep. 
MassChallenge. (2014). Impact Report 2014. Boston, USA: MassChallenge.

Schreiber, U., \& Pinelli, M. (2013). The power of three: Together, governments, entrepreneurs and corporations can spur growth across the G20. The EY G20 Entrepreneurship Barometer. EYGM Limited.

Schwartz, M., Goethner, M., Michelsen, C., \& Waldmann, N. (2013). Start-up competitions as an instrument of entrepreneurship policy: The German experience. European Planning Studies, 21(10), 1578-1597. https://doi.org/10.1080/09654313.2012.722960

Startupticker.ch. (2016). Swiss venture capital report 2016.

Venture, K. (2015). Venture Kick annual report 2015. Startup Space.

Witt, M. A., \& Redding, G. (2012). The spirits of corporate social responsibility: Senior executive perceptions of the role of the firm in society in Germany, Hong Kong, Japan, South Korea and the USA. Socio-Economic Review, 10(1), 109-134. https://doi.org/10.1093/ser/mwr026

\section{Appendix A}

List of major venture competitions and supporting organizations in Switzerland

\begin{tabular}{|c|c|}
\hline $\begin{array}{l}\text { Venture competitions } \\
\text { and supporting organizations }\end{array}$ & Description \\
\hline $\begin{array}{l}\text { IMD startup competition } \\
\text { www.imd.ch/startups }\end{array}$ & $\begin{array}{l}\text { Organized by IMD business school, for early stage ventures, } \\
\text { providing collaboration with MBA students }\end{array}$ \\
\hline $\begin{array}{l}\text { Venture Kick } \\
\text { http://www.venturekick.ch }\end{array}$ & $\begin{array}{l}\text { A philanthropic initiative by a private consortium for early detection } \\
\text { and financing promising business ideas. Applicant must be a } \\
\text { member of a Swiss university or a school of higher education }\end{array}$ \\
\hline $\begin{array}{l}\text { De Vigier Prize } \\
\text { www.devigier.ch } \\
\text { >>venture>> (McKinsey) } \\
\text { http://www.venture.ch }\end{array}$ & $\begin{array}{c}\text { Organized by the de Vigier foundation in Switzerland, for innovative } \\
\text { and promising product ideas. Applicants must be Swiss citizens } \\
\text { Organized by ETH and McKinsey. Business plan competition } \\
\text { combined with learning events and coaching }\end{array}$ \\
\hline $\begin{array}{l}\text { Venture Leaders } \\
h \mathrm{htt} \text { ///www venturelab ch }\end{array}$ & Selection of Swiss entrepreneurs providing Venturelab and a group \\
\hline $\begin{array}{l}\text { Trophée PERL } \\
\text { http://www.lausanneregion.ch }\end{array}$ & $\begin{array}{c}\text { Le Prix Entreprendre Région Lausanne (PERL) for start-ups in the } \\
\text { Lausanne region }\end{array}$ \\
\hline $\begin{array}{l}\text { Prix Strategis } \\
\text { www.prixstrategis.ch }\end{array}$ & The Strategis Award is organized by the University of Lausanne \\
\hline $\begin{array}{l}\text { Innogrant EPFL } \\
\text { http://vpiv.epfl.ch/innogrants }\end{array}$ & $\begin{array}{c}\text { Grants awarded by EPFL to promote a spin-off in the form of } \\
\text { one-year salary as an employee in one of the university's } \\
\text { laboratories }\end{array}$ \\
\hline $\begin{array}{l}\text { STARTUP.CH award } \\
\text { http://www.startup.ch }\end{array}$ & $\begin{array}{l}\text { Annual business plan competition. The best Swiss start-ups are } \\
\text { awarded annually with the TOP } 100 \text { STARTUP AWARD. }\end{array}$ \\
\hline $\begin{array}{l}\text { Entrepreneur of the Year (EY) } \\
\text { http://www.ey.com/CH/en/About-us/Entrepreneurshi } \\
\text { p/Entrepreneur-Of-The-Year }\end{array}$ & $\begin{array}{l}\text { Sponsored by EY, held in } 60 \text { countries around the world, to } \\
\text { recognize the accomplishments of entrepreneurs }\end{array}$ \\
\hline $\begin{array}{l}\text { Heuberger Winterthur Jungunternehmerpreis } \\
\text { http://www.jungunternehmer-preis.ch }\end{array}$ & $\begin{array}{l}\text { Young entrepreneur's award granted by the real estate entrepreneur } \\
\text { Robert Heuberger, for German-speaking Swiss entrepreneurs, for all } \\
\text { types of business ventures with high growth potential }\end{array}$ \\
\hline $\begin{array}{c}\text { Swiss Technology Award } \\
\text { https://www.swiss-innovation.com/en/informations/ }\end{array}$ & To promote technology-based innovations and developments \\
\hline $\begin{array}{c}\text { Swiss Economic Award } \\
\text { http://www.swisseconomic.ch/en/award }\end{array}$ & $\begin{array}{l}\text { Organized by Swiss Economic Forum, annual award for Swiss } \\
\text { entrepreneurs with outstanding achievements }\end{array}$ \\
\hline $\begin{array}{c}\text { Commission for Technology } \\
\text { and Innovation (CTI) } \\
\text { https://www.innosuisse.ch/inno/en/home.html }\end{array}$ & $\begin{array}{l}\text { An arm of the Swiss Federal Government, supporting innovation } \\
\text { and entrepreneurship through coaching, training, networking and } \\
\text { R\&D investments }\end{array}$ \\
\hline
\end{tabular}

\section{Copyrights}

Copyright for this article is retained by the author(s), with first publication rights granted to the journal.

This is an open-access article distributed under the terms and conditions of the Creative Commons Attribution license (http://creativecommons.org/licenses/by/4.0/). 